\title{
A JUDICIALIZAÇÃO DO DIREITO À SAÚDE NO CONSTITUCIONALISMO BRASILEIRO: ESCASSEZ, CUSTOS E EFICIÊNCIA ECONÔMICO-SOCIAL
}

\author{
THE JUDICIALIZATION OF THE RIGHT TO HEALTH ON BRAZILIAN \\ CONSTITUTIONALISM: SCARCITY, COSTS AND SOCIOECONOMIC EFFICIENCY
}

\author{
LA JUDICIALIZACIÓN DEL DERECHO A LA SALUD EN EL \\ CONSTITUCIONALISMO BRASILEÑO: ESCASEZ, COSTOS Y EFICIENCIA \\ SOCIOECONÓMICA
}

\section{EVERTON DAS NeVES GONÇALVES}

https://orcid.org/0000-0002-5116-9362 / http:/ / lattes.cnpq.br/7522914289995130 / evertong@vetorial.net

Doutor em Direito Econômico pela Universidade Federal de Minas Gerais. Doctor en Derecho Internacional Económico por la Universidad de Buenos Aires. Professor Associado IV, credenciado no Programa de Pós-Graduação em Direito da Universidade Federal de Santa Catarina (PPGD/UFSC). Coordenador do Centro de Estudos JurídicoEconômicos e de Gestão para o Desenvolvimento (CEJEGD) do Centro de Ciências Jurídicas (CCJ/UFSC). Florianópolis, SC, Brasil.

MARCo AURÉLIo SOUZA DA SiLVA

https://orcid.org/0000-0003-2182-6787 http://lattes.cnpq.br/4661913076719703/ marcoaurelio_vet@yahoo.com.br Doutorando e Mestre em Direito pela Universidade Federal de Santa Catarina (UFSC). Auditor Fiscal de Controle Externo do Tribunal de Contas do Estado de Santa Catarina. Florianópolis, SC, Brasil.

\section{RESUMO}

A Carta Política de 1988 estabeleceu que a saúde é direito de todos e dever do Estado. Diante da incapacidade do Poder Executivo em dar efetividade a esse direito, o Poder Judiciário tem obrigado o Estado a custear medicamentos pleiteados individualmente. 0 problema se refere aos limites das determinações judiciais. As concessões individuais também prejudicam o atendimento coletivo, desorganizam as contas públicas e deslocam recursos previamente programados. Partindo do método dedutivo, o estudo tem por objetivo evidenciar que a escassez dos recursos públicos conduz à ideia de que a efetivação do direito individual à saúde apresenta custos econômicos que geram consequências para a coletividade. Conclui-se que a decisão judicial, nesses casos, não deve prescindir dos fundamentos econômicos e consequencialistas da análise econômica.

Palavras-chave: Custos; Saúde; Eficiência; Escassez; Judicialização.

\begin{abstract}
The Constitution of 1988 has determined that health is a right for all and a government obligation. Faced with the inability of the Executive Branch to ensure this right, the Judiciary Branch has compelled the government to pay for the drugs that are being applied for individually. The problem refers to the limits of the judicial stipulations. Individual concessions also jeopardize collective service, disrupt public accounts and displace resources previously planned. Starting from a deductive method, the study aims to emphasize the scarcity of public resources leads to the idea that the establishment of the individual right to health has economic costs that results in consequences for the public. The conclusion is that the decision of the court, in these cases, should not dispense with the economic fundamentals and consequences of economic analysis.
\end{abstract}

Keywords: Costs; Health; Efficiency; Scarcity; Judicialization. 


\section{RESUMEN}

La Carta Política de 1988 estableció que la salud es derecho de todos y deber del Estado. Ante de la incapacidad del Poder Ejecutivo en dar efectividad a ese derecho, el Poder Judicial ha obligado al Estado a costear medicamentos pleiteados individualmente. El problema se refiere a los límites de las determinaciones judiciales. Las concesiones individuales también perjudican la atención colectiva, desorganizan las cuentas públicas y dislocan recursos previamente programados. Partiendo del método deductivo, el estudio tiene por objetivo evidenciar que la escasez de los recursos públicos conduce a la idea de que la efectivación del derecho individual a la salud presenta costos económicos que generan consecuencias para la colectividad. Se concluye que la decisión judicial, en esos casos, no debe prescindir de los fundamentos económicos y consecuencialistas del análisis económico.

Palabras clave: Costos; Salud; Eficiencia; Escasez; Judicialización.

\section{SUMÁRIO}

INTRODUÇAO; 1. O CONSTITUCIONALISMO E A ONDA TARDIA QUE ATINGE O BRASIL; 2. O DÉFICIT DE REPRESENTATIVIDADE POLÍTICA E A ASCENSÃO DO PODER JUDICIÁRIO; 3. A JUDICIALIZAÇÃO DA POLÍTICA E A SEPARAÇÃO DOS PODERES; 4. A JUDICIALIZAÇÃO DO DIREITO FUNDAMENTAL À SAÚDE E A ESCASSEZ DE RECURSOS ORÇAMENTÁRIOS; 5. OS DIREITOS SOCIAIS TÊM CUSTOS?; 6. O PRINCÍPIO DA EFICIÊNCIA ECONÔMICO-SOCIAL (PEES); 7. O CONSELHO NACIONAL DE JUSTIÇA E A BUSCA DE MAIOR EFICIÊNCIA NA SOLUÇÃO DAS DEMANDAS JUDICIAIS; 8. UM CASO CONCRETO PARA PENSAR NOS CUSTOS DO DIREITO FUNDAMENTAL À SAÚDE; CONCLUSÃO; REFERÊNCIAS.

\section{INTRODUÇÃO}

O ambiente de redemocratização no Brasil, operado no final do século XX, é marcado pela Constituição de 1988, que pode ser considerada uma das mais inovadoras e progressistas, sobretudo no tocante à garantia de direitos fundamentais socais. Se, por um lado, esse marco político-jurídico inovou em termos de previsão normativa de direitos sociais e de sua universalização, por outro, não levou em conta os aspectos econômico-financeiros do Estado para o seu custeio. De lá para cá, nesse modelo social que exige intervenção efetiva do Estado, uma das questões sempre presentes no debate do constitucionalismo diz respeito à baixa concretização de direitos sociais por parte de políticas públicas e a limitada capacidade orçamentária do Estado de custear despesas com tais direitos, situação que tem perenizado históricas injustiças sociais no país.

Em meio à combalida capacidade política dos Poderes Executivo e Legislativo, o Poder Judiciário assumiu nos últimos anos a posição de protagonista na efetivação de políticas públicas, cujo ativismo judicial tem sido mais conhecido como "judicialização da política". No âmbito das políticas que veiculam direitos sociais, a saúde ocupa um lugar de destaque em termos de déficit de concretização, razão pela qual a intensa demanda perante o Poder Judiciário recebe o rótulo específico de "judicialização do direito à saúde”. 
ISSN 1981-3694

(DOI): $10.5902 / 1981369429084$

A JUDICIALIZAÇÃO DO DIREITO À SAÚDE NO

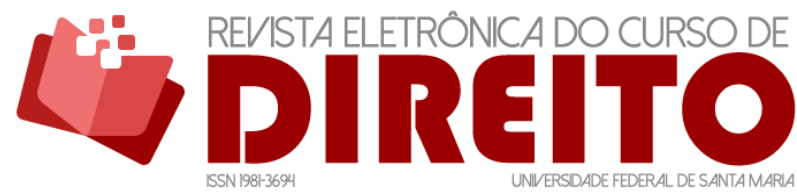
CONSTITUCIONALISMO BRASILEIRO: ESCASSEZ, CUSTOS E EFICIÊNCIA ECONÔMICO-SOCIAL

EVERTON DAS NEVES GONÇALVES MARCO AURÉLIO SOUZA dA SILVA

0 problema que se pretende enfrentar com o presente estudo se refere aos limites da obrigação judicial de o ente federativo custear irrestritamente tratamento ou medicamento para pessoas que não possuem recursos financeiros suficientes. De um lado, está a necessidade de dar efetividade individual a um direito fundamental constitucionalmente assegurado e, de outro, a limitada capacidade orçamentária do Estado em custear despesas dessa natureza de forma não programada, desequilibrando as contas públicas e prejudicando o atendimento coletivo. Como pano de fundo estão as concepções de custos dos direitos, escassez, separação dos poderes e eficiência.

Adotando-se o método dedutivo e o referencial teórico da análise econômica do direito, a partir da pesquisa interdisciplinar no campo do direito constitucional e da economia, o objetivo do estudo é demonstrar que a concretização do direito fundamental à saúde, pela via do Poder Judiciário, além de afrontar a separação dos poderes, privilegia o atendimento individual em detrimento do coletivo. A situação não apenas revela a ineficiência estatal como também os reflexos irreparáveis que o ativismo judicial produz no Poder Executivo, especialmente no que respeita ao desequilíbrio orçamentário e à liberalidade de alocação de recursos pelo administrador, eleito pela vontade popular e por seu programa de governo.

Estrutura-se o artigo inicialmente com uma abordagem sobre as ondas internacionais de constitucionalização e o momento em que esse modelo atinge o país. Nos dois tópicos seguintes, abordam-se o déficit de representatividade política e a ascensão do Poder Judiciário, seguido de uma análise sobre a judicialização da política e a separação dos poderes. No quarto tópico, traça-se um panorama entre a judicialização do direito fundamental à saúde e a escassez de recursos orçamentários. Na sequência, abordam-se os custos dos direitos sociais e o Princípio da Eficiência Econômico-Social (PEES). No sétimo tópico, comenta-se sobre o papel desenvolvido pelo Conselho Nacional de Justiça na busca de melhor eficiência nas demandas judiciais de saúde e, ao final, ilustra-se a problemática com a análise de um caso concreto que ensejou o primeiro Incidente de Resolução de Demandas Repetitivas (IRDR) pelo Tribunal de Justiça de Santa Catarina sobre a concessão de medicamentos e que passou a servir de parâmetro para os demais casos envolvendo a matéria no Estado catarinense.

\section{CONSTITUCIONALISMO E A ONDA TARDIA QUE ATINGE O BRASIL}

O constitucionalismo está ligado ao fenômeno de criação de Constituições nos Estados em determinado momento histórico. 0 processo de constitucionalização nos diversos cantos do 
ISSN 1981-3694

(DOI): $10.5902 / 1981369429084$

A JUDICIALIZAÇÃO DO DIREITO À SAÚDE NO

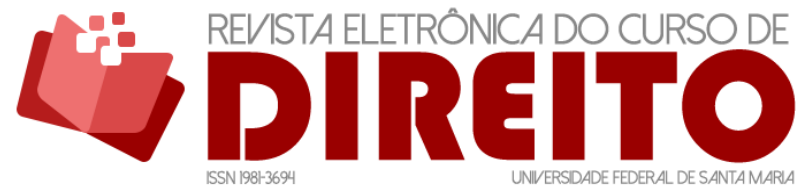
CONSTITUCIONALISMO BRASILEIRO: ESCASSEZ, CUSTOS E EFICIÊNCIA ECONÔMICO-SOCIAL

EVERTON DAS NEVES GONÇALVES MARCO AURÉLIO SOUZA dA SILVA

mundo se deu gradativamente, ao que Elster convencionou chamar de "ondas de constitucionalização", que mais precisamente se limitam ao número de sete. ${ }^{1} \mathrm{Na}$ concepção do autor, os modernos processos de elaboração da Constituição iniciaram no século XVIII (entre 1780 e 1791), onde constituições foram escritas pelos Estados Unidos, pela Polônia e França, sendo considerada a primeira onda. A seguinte ocorreu após as revoluções de 1948, na Europa, chegando a uma terceira onda após a Primeira Guerra Mundial, quando o Estado alemão, derrotado, adotou a Constituição de Weimar.

A quarta onda ocorreu após a Segunda Guerra Mundial, ocasião em que os países derrotados (Japão, Alemanha e Itália) adotaram novas Constituições sob a tutela dos aliados. A quinta onda se relaciona com a dissolução dos impérios coloniais inglês e francês, enquanto a seguinte está relacionada com a queda das ditaduras na Europa meridional em meados dos anos 1970 (Portugal, Grécia e Espanha). Por fim, Elster registra como a sétima onda de constitucionalização o momento em que um número de antigos países comunistas na Europa Leste e Central adotaram novas Constituições depois da queda do comunismo, em 1989.

O fim da Segunda Guerra Mundial é considerado um marco histórico importante para o constitucionalismo, considerando a visibilidade e a repercussão das graves violações produzidas contra os direitos humanos. A partir desse momento, especialmente nos países da Europa (Alemanha, Itália, França, Portugal, Espanha, por exemplo), houve uma crescente demanda por mecanismos que garantissem direitos fundamentais e limitassem os poderes dos governantes e, consequentemente, um significativo redesenho institucional e dogmático-jurídico. No plano institucional, ganha destaque a criação de tribunais constitucionais, enquanto que, no dogmático-jurídico, o direito constitucional passa por uma reconfiguração a partir da elaboração de novas constituições e de sua centralidade no ordenamento jurídico.

Schmitt ressalta que a história dos direitos fundamentais inicia propriamente com as declarações formuladas pelos Estados americanos no século XVIII, ao fundar sua independência em relação à Inglaterra, tendo sido a primeira declaração emitida pelo Estado da Virgínia, em 1776. ${ }^{2}$ Salienta que na Revolução Francesa, de 1789, surge a Constituição moderna, mista de elementos liberais e democráticos, baseada na teoria do Poder Constituinte, cuja dogmática política influenciará a construção jurídica de caráter positivo da moderna Teoria da

\footnotetext{
${ }^{1}$ ELSTER, Jon. Forças e mecanismos no processo de elaboração da Constituição. In: BIGONHA, Antonio Carlos Alpino; MOREIRA, Luiz (orgs). Limites do Controle de Constitucionalidade. Rio de Janeiro: Lumen Juris, 2009, p. 13-14.
}

${ }^{2}$ SCHMITT, Carl. Teoria de la Constitución. Madrid: Alianza Editorial [1928], 2006, p. 164-165. 
ISSN 1981-3694

(DOI): $10.5902 / 1981369429084$

A JUDICIALIZAÇÃO DO DIREITO À SAÚDE NO

U U DIREITO CONSTITUCIONALISMO BRASILEIRO: ESCASSEZ, CUSTOS E EFICIÊNCIA ECONÔMICO-SOCIAL

EVERTON DAS NEVES GONÇALVES MARCO AURÉlIO SOUZA dA SILVA

Constituição. ${ }^{3}$ Os mais importantes direitos fundamentais dessas declarações eram a liberdade, a propriedade privada, a segurança, o direito de resistência e as liberdades de consciência e de religião.

Se até o século XIX prevalecia o Estado Legislativo de Direito, fundado em uma soberania parlamentar que conferia ao Legislativo a função de estabelecer direitos fundamentais por meio da elaboração de normas, a partir desse período tal modelo cedeu lugar ao Estado Constitucional e Democrático de Direito, ocasião em que a Constituição passou a ser o parâmetro de validade e interpretação de todas as normas jurídicas, abrindo espaço para um modelo designado de constitucionalismo do pós-guerra, novo direito constitucional ou neoconstitucionalismo.

Essa nova linha teórica se encontra ligada a algumas demarcações. Barroso identifica o neoconstitucionalismo com as transformações ocorridas no Estado e no direito constitucional, notadamente com o pós-positivismo (marco filosófico), a formação do Estado Constitucional de Direito (marco histórico) e o reconhecimento da força normativa da Constituição, a expansão da jurisdição constitucional e o desenvolvimento de uma nova dogmática de interpretação constitucional (marco teórico). ${ }^{4}$

O modelo de constitucionalismo, no qual as Constituições passaram a ser vistas como normas jurídicas supremas, ultrapassou as fronteiras da Europa e ganhou o mundo. Na medida em que essas Constituições contemplaram o espectro de jurisdição, limitaram poderes, organizaram o Estado e o exercício do poder político, também garantiram direitos individuais e sociais, inclusive fixando normas programáticas para condicionar as políticas públicas estatais para um momento futuro.

O Brasil não ficou alheio a essa onda de constitucionalização, coincidindo tardiamente com o processo de redemocratização operado no final do século $X X$, com destaque para a Constituição de 1988, inovadora e progressista, sobretudo quanto à garantia estatal de direitos fundamentais sociais, hoje tão caros quando se fala de concretização.

\section{O DÉFICIT DE REPRESENTATIVIDADE POLÍTICA E A ASCENSÃO DO PODER JUDICIÁRIO}

\footnotetext{
${ }^{3}$ SCHMITT, Carl. Teoria de la Constitución. Madrid: Alianza Editorial [1928], 2006, p. 70-71.

${ }^{4}$ BARROSO, Luís Roberto. A razão sem voto: o Supremo Tribunal Federal e o governo da maioria. In: SARMENTO, Daniel (Coord.). Jurisdição constitucional e política. Rio de Janeiro: Forense, 2015, p. 07.
} 
Institucionalmente, o período de 1964 a 1985 no Brasil é revelado por um regime repressor e violador de direitos humanos, alicerçado na Doutrina da Segurança Nacional. A constitucionalização do novo regime, de acordo com Rocha, deu-se com a Carta Constitucional de 1967, ao criar um sistema político com vasta concentração de poderes no Executivo, ao nível da União. A presidência da república se tornava, assim, o órgão máximo do regime, sendo o presidente eleito pelo sufrágio de um colégio eleitoral e os governadores de Estado, prefeitos de capitais e de municípios escolhidos exclusivamente pelo chefe de Estado. Ganha relevo nesse período, em 1969, a Emenda Constitucional (EC n. 1) feita à Constituição de 1967, revelando a dimensão repressora do regime por meio do Ato Institucional n. $5 .^{5}$

O regime ditatorial enfrentou críticas por parte de diversos setores da sociedade (universidade, igreja católica, $O A B$ e outros), centradas na denúncia de violações aos direitos humanos perpetradas pelo aparelho repressor, por meio do maciço e sistemático uso da violência, prisões e tortura contra os chamados "subversivos" do regime. ${ }^{6}$ A movimentação de setores sociais organizados e poderosos ${ }^{7}$ e, especialmente, de facções ideologicamente interessadas na manutenção de seu status quo, culminou com o processo constituinte num ambiente de redemocratização e a elaboração de um documento inovador e progressista - a Constituição de 1988 -, que então marcava a passagem do autoritarismo para a democracia no Brasil. ${ }^{8} \mathrm{O}$ fato de ter havido muitas facções influenciou o processo constituinte, de maneira que a dinâmica dos trabalhos foi resultado dos interesses dos grupos mais organizados, e não necessariamente fruto de um grande acordo do povo.

Entre outras características está a de que a Constituição de 1988 deu ao Poder Judiciário brasileiro um leque de atribuições, ao ponto de possibilitar a esse órgão, inclusive,

\footnotetext{
${ }^{5}$ ROCHA, Antônio Sérgio. Genealogia da Constituinte: do autoritarismo à democratização. Lua Nova. v. 88, 2013, p. 32-33.

${ }^{6}$ ROCHA, Antônio Sérgio. Genealogia da Constituinte: do autoritarismo à democratização. Lua Nova. v. 88, 2013, p. 44-45.

${ }^{7}$ Sobre esse papel de setores sociais organizados e poderosos, vale registrar a concepção de Holmes, para quem o direito constitucional reflete as assimetrias de poder, de modo que as Constituições emergem e sobrevivem porque servem aos interesses perseguidos pelas forças sociais mais bem organizadas e mais poderosas (HOLMES, Stephen. Constituições e constitucionalismo. In: ASENSI, Felipe. PAULA, Daniel Giotti de (orgs.). Tratado de Direito Constitucional. v. 2. Rio de Janeiro: Elsevier, 2014, p. 600-607).

${ }^{8}$ Araújo descreve sinteticamente a sucessão dos fatos da seguinte forma: começa com a derrota da Arena para o MDB na eleição do Senado, em 1974; passa pela crescente incapacidade dos governos autoritários (de Geisel a Figueiredo) de enfrentar a seu modo a crise econômica e os conflitos sociais dela resultantes; pela derrota dos candidatos do regime nas eleições para os principais governos estaduais e a perda de sua maioria na Câmara Federal, em 1982; até culminar com a campanha oposicionista das eleições diretas e a consequente perda da capacidade do regime de fazer unilateralmente seu sucessor presidencial, em 19841985 (ARAÚJO, Cícero. O processo constituinte brasileiro, a transição e o poder constituinte. Lua Nova. v. 88,2013 , p. 358 ).
} 
realizar uma interpretação para reduzir o positivismo formalista (que buscava equiparar o direito às ciências naturais e concebia a norma como objeto científico) em suas decisões, colocando em seu lugar métodos de ponderação e argumentação principiológica fundada em valores, a fim de promover transformações sociais no vácuo omissivo do Poder Legislativo. Um exemplo claro é o que se observa no exercício do controle de constitucionalidade das leis.

No desempenho do controle de constitucionalidade, o Poder Judiciário muitas vezes invalida atos normativos emanados dos Poderes Legislativo e Executivo, editados em desconformidade com a Constituição, isso quando não estabelece normas ao arrepio do legislador. É nesse contexto que nasce a discussão acerca da legitimidade democrática de sua atividade, lembrando o famoso e fecundo debate entre Schmitt e Kelsen sobre quem deveria ser o guardião da Constituição9 , na medida em que a interpretação que o Poder Judiciário faz da Constituição acaba por se sobrepor àquela feita pelos agentes políticos investidos de mandato representativo. Cuida-se de uma aparente incongruência no âmbito de um Estado democrático, denominada de "dificuldade contramajoritária"10, dada a ilegitimidade dos juízes não eleitos pelo voto popular para invalidarem as decisões tomadas pelos agentes políticos eleitos pelo povo.

Nesse ponto, como adverte Barroso, vale salientar a predominância da aceitação do papel contramajoritário do controle de constitucionalidade, que se assenta em dois fundamentos principais: a) a proteção dos direitos fundamentais, correspondentes ao mínimo ético e à reserva de justiça, insuscetíveis de serem atropelados por deliberação política majoritária; e b) a proteção das regras do jogo democrático e dos canais de participação política de todos. ${ }^{11}$

Entre as razões do espaço construído pelo Poder Judiciário a partir da Constituição de 1988 estão a complexidade das relações sociais contemporâneas e a crise de representação

\footnotetext{
${ }^{9}$ Schmitt sustentou que caberia ao Presidente do Reich (Executivo), e não ao Judiciário, a tarefa de salvaguardar a Constituição, enquanto Kelsen defendeu que esse papel deveria ser de um Tribunal de Justiça Constitucional. Não obstante o esmero argumentativo e crítico de Schmitt em relação ao Parlamento de sua época, o vencedor do debate foi Kelsen, considerando a projeção histórica de seu pensamento, que culminou com a preponderância do sistema de Tribunais Constitucionais ao longo da segunda metade do século XX nos países democráticos. As consequências desse debate repercutem de maneira bastante atual no Brasil, quando se confrontam os papeis do Executivo e do Judiciário, notadamente pela interpretação que o Poder Judiciário tem feito da Constituicão nos últimos anos (SCHMITT, Carl. O Guardião da Constituição. Belo Horizonte: Del Rey, 2007, p. 19-71 e 193-234; KELSEN, Hans. Jurisdição Constitucional. São Paulo: Martins Fontes, 2003, p. 239-298).

${ }^{10}$ Segundo a teoria constitucional, a expressão se tornou clássica a partir da obra de BICKEL, Alexander. The least dangerous branch: the Supreme Court at the bar of politics. Indianápolis: Bob-Merrill Educational Publishing, 1962.

11 BARROSO, Luís Roberto. A razão sem voto: o Supremo Tribunal Federal e o governo da maioria. In: SARMENTO, Daniel (Coord.). Jurisdição constitucional e política. Rio de Janeiro: Forense, 2015, p. 19.
} 
ISSN 1981-3694

(DOI): $10.5902 / 1981369429084$

A JUDICIALIZAÇÃO DO DIREITO À SAÚDE NO

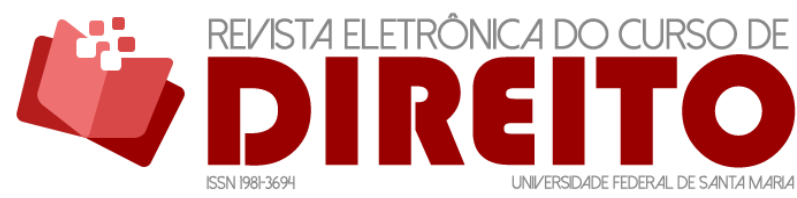
CONSTITUCIONALISMO BRASILEIRO: ESCASSEZ, CUSTOS E EFICIÊNCIA ECONÔMICO-SOCIAL

EVERTON DAS NEVES GONÇALVES MARCO AURÉlIO SOUZA dA SILVA

política. É bem verdade que o descontentamento, o desinteresse e o ceticismo dos cidadãos para com a classe política não é um sintoma apenas do Estado democrático brasileiro. Os meios de comunicação de massa quase que diariamente dão conta de desvios de dinheiro público, corrupção, abuso de poder econômico e sobreposição de interesses privados em relação aos interesses públicos, comumente envolvendo a classe política.

0 grave déficit de representatividade das instituições políticas restou clarividente nas manifestações populares que tomaram as ruas do País em junho de 2013 e que se seguiram em diversas outras oportunidades, no impeachment da Presidente da República e mais recentemente nos desdobramentos da Operação Lava-Jato, revelando a corrupção entre empresários e políticos. Tal situação acaba sendo ainda mais dramática quando o Parlamento se omite de legislar sobre questões que afetam diretamente a vida da coletividade, deixando o espaço da solução política (majoritária) para a solução judicial (contramajoritária).

\section{A JUDICIALIZAÇÃO DA POLÍTICA E A SEPARAÇÃO DOS PODERES}

Nesse cenário delineado anteriormente, o Poder Judiciário passou a se autolegitimar representante das demandas sociais, sendo o neoconstitucionalismo o pano de fundo para a concretização dos ideais emancipatórios e de justiça albergados na Constituição. No entanto, considerando o espaço privilegiado que deve ter a política, como expressão da vontade majoritária, não resta dúvida de que se está diante de uma distorção (se é que se pode falar assim) da democracia representativa no Brasil. Não é por outra razão que esse fenômeno de expansão da jurisdição constitucional chegou a um ponto na vida pública nacional que sua atuação político-social tem sido identificada como “judicialização da política”. E, tão importante quanto à “judicialização da política” é também a “politização da justiça”, identificada como o uso da jurisdição pelos magistrados para atividades tipicamente políticas, o que também não pode ser ignorado.

A expansão da judicialização da política, concebida como a participação cada vez maior do Poder Judiciário na elaboração de políticas públicas que antes eram realizadas pelos Poderes Executivo e Legislativo, tem sido revelada pela intensa exposição midiática das decisões do Supremo Tribunal Federal em casos paradigmáticos, de grande repercussão na opinião pública, no campo das questões morais que giram em torno dos direitos fundamentais e dos processos político-eleitorais. Entre os casos, podem ser citados o de reconhecimento das uniões estáveis homoafetivas, o do direito de greve dos servidores públicos, o de fidelidade partidária, o da 
ISSN 1981-3694

(DOI): $10.5902 / 1981369429084$

A JUDICIALIZAÇÃO DO DIREITO À SAÚDE NO

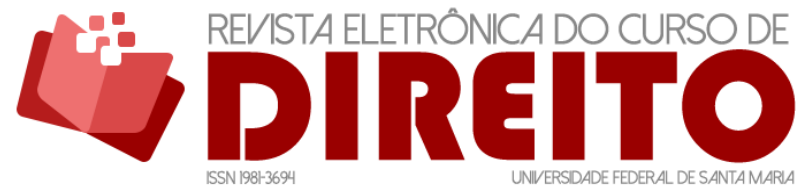
CONSTITUCIONALISMO BRASILEIRO: ESCASSEZ, CUSTOS E EFICIÊNCIA ECONÔMICO-SOCIAL

EVERTON DAS NEVES GONÇALVES MARCO AURÉLIO SOUZA dA SILVA

aplicabilidade da Lei da Ficha Limpa, o das cláusulas de barreira à criação ou permanência de partidos políticos, o de pesquisa com células-tronco embrionárias, o de interrupção da gestação de fetos anencefálicos, o de uso de algemas, o de progressão de regime prisional, o de liberdade de expressão e manifestações favoráveis à descriminalização das drogas, o de cotas para ingresso no ensino superior em instituições públicas, o de não recepção da Lei de Imprensa da ditadura militar, o de nepotismo na Administração Pública, entre outros especialmente resultantes dos desdobramentos da Operação Lava-Jato, que investiga atos de corrupção envolvendo contratos com o Poder Público e financiamentos de campanhas eleitorais.

É sabido que os juízes não vivem em completo isolamento da política. Por isso, o debate acerca da judicialização da política é sobre os limites decisórios do Poder Judiciário sob o aspecto da legitimidade democrática. Não há dúvidas de que deve ser incentivada a jurisdição que valorize a irradiação das normas constitucionais pelo ordenamento jurídico e a atuação construtiva do Poder Judiciário para a proteção e promoção dos direitos fundamentais sociais e dos pressupostos da democracia. No entanto, vale ressaltar a advertência de Sarmento e Souza Neto $^{12}$, para quem devem ser evitadas as concepções radicais do neoconstitucionalismo que endossem um "governo de juízes" ou aplaudam o decisionismo judicial, fundamentadas numa invocação emotiva de princípios e valores constitucionais, assim como evitada a hiperconstitucionalização do direito que suprime o espaço necessário da política majoritária.

Em sede de judicialização da política, a discussão está longe de seu fim, porquanto se encontra circunscrita ao candente debate envolvendo a separação dos poderes, um dos pilares do constitucionalismo. De modo geral, a separação dos poderes é vista como uma forma de impedir interferências de um poder em outro, o que de certo modo não deixa de ser uma visão simplista, como alerta Holmes, de que a autoridade é dividida para evitar excessivas concentrações de poder, onde um ramo do governo pode "frear" o outro, inibindo o despotismo ou revelando a corrupção. No entanto, salienta o autor, é preciso ter em mente que a separação de poderes também possui a função de aumentar o poder. ${ }^{13}$

Seguindo a mesma linha, Waldron afirma que a concepção de separação formal dos Poderes Legislativo, Executivo e Judiciário, como uma maneira de diluir o poder, tornando mais difícil o seu exercício, não deve ser vista apenas pela lente da restrição e da limitação, mas

\footnotetext{
12 SOUZA NETO, Cláudio Pereira de; SARMENTO, Daniel. Controle de constitucionalidade e democracia: algumas teorias e parâmetros de ativismo. In: SARMENTO, Daniel (Coord.). Jurisdição constitucional e política. Rio de Janeiro: Forense, 2015, p. 100.

${ }^{13}$ HOLMES, Stephen. El Precompromiso y la paradoja de la democracia. In: ELSTER, Jon. SLAGSTAD, Rune (orgs). Constitucionalismo y democracia. Fondo de Cultura Economico: México, 1999, p. 19-20.
} 
ISSN 1981-3694

(DOI): $10.5902 / 1981369429084$

A JUDICIALIZAÇÃO DO DIREITO À SAÚDE NO

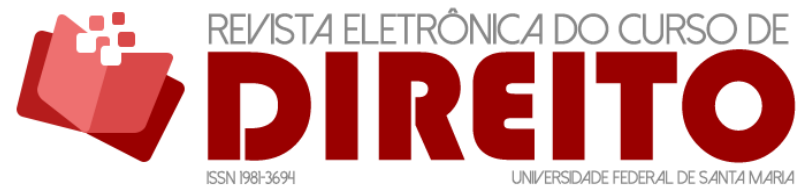
CONSTITUCIONALISMO BRASILEIRO: ESCASSEZ, CUSTOS E EFICIÊNCIA ECONÔMICO-SOCIAL

EVERTON DAS NEVES GONCALVES MARCO AURÉLIO SOUZA dA SILVA

como uma forma de levar a sério a integridade de um verdadeiro exercício legislativo, a fim de compreender a importância de uma Constituição a partir da possibilidade de alojamento para a atividade política de uma sociedade. ${ }^{14}$

Um efeito da judicialização da política e da separação dos poderes, por exemplo, pode ser percebido na atuação do Poder Judiciário em questões relacionadas à judicialização do direito à saúde, como se verá a seguir.

\section{A JUDICIALIZAÇÃO DO DIREITO FUNDAMENTAL À SAÚDE E A ESCASSEZ DE RECURSOS ORÇAMENTÁRIOS}

Parece consenso que a Carta Política de 1988 inaugurou uma nova fase do constitucionalismo brasileiro, notadamente quando atribuiu ao Estado, entre outros, o papel central de promotor da transformação social por meio de prestações positivas ${ }^{15}$ veiculadas por políticas públicas que assegurem direitos fundamentais individuais e sociais. Por decorrência direta da democracia representativa (e também participativa), é possível estabelecer que a elaboração e a execução das políticas públicas são atribuições dos Poderes Legislativo e Executivo, respectivamente.

De modo geral, as políticas públicas correspondem a instrumentos colocados à disposição do Estado com o escopo de concretização de direitos fundamentais. Conquanto haja várias possibilidades de conceituação jurídica do termo "políticas públicas", aproveita-se aqui o conceito desenvolvido por Bucci, para quem a expressão “política pública” corresponde a um programa de ação governamental, resultante de um processo ou conjunto de processos juridicamente regulados, visando a coordenar os meios à disposição do Estado e as atividades privadas, para a realização de objetivos socialmente relevantes e politicamente determinados. ${ }^{16}$

Em sede de políticas públicas, a saúde ocupa um lugar de destaque. 0 direito à saúde constitui um dos direitos sociais positivados na Constituição (art. $6^{\circ}$ ), concebido como direito de

\footnotetext{
${ }^{14}$ WALDRON, Jeremy. Political Political Theory: essays on institutions. Cambridge: Harvard University Press, 2016, p. 35-36.

${ }^{15}$ De acordo com Alexy, "todo direito a uma ação positiva, ou seja, a uma ação do Estado, é um direito a uma prestação. Nesse sentido, o conceito de direito a prestações é exatamente o oposto do conceito de direito de defesa, no qual se incluem todos os direitos a uma ação negativa, ou seja, a uma abstenção estatal" (ALEXY, Robert. Teoria dos direitos fundamentais. 2. ed. São Paulo: Malheiros Editores, 2011, p. 442).

${ }^{16}$ BUCCl, Maria Paula Dallari. O conceito de política pública em direito. In: BUCCI, Maria Paula Dallari (Org.). Políticas públicas: reflexões sobre o conceito jurídico. São Paulo: Saraiva, 2006, p. 39.
} 
todos e dever do Estado (art. 196). Em função desse comando que obriga todos os entes federados a proteger a saúde, foi criado o Sistema Único de Saúde (SUS), com direção única em cada esfera de governo e estrutura descentralizada para atendimento integral (art. 198). A norma geral que contém as diretrizes a serem seguidas pela União, pelos Estados e Municípios é a Lei n. 8.080/90, denominada Lei Orgânica da Saúde ${ }^{17}$. Entre os princípios que norteiam a saúde estão o da universalidade (acesso a todos), da equidade (acesso em condições iguais), da integralidade (atendimento e acompanhamento, clínico e de gastos, ao longo do tratamento) e da descentralização (União, Estados e Municípios).

Devido à insuficiente concretização de políticas públicas voltadas à área da saúde pelos entes federados, o Poder Judiciário tem sido chamado a intervir com frequência em favor de sua garantia mediante o controle de constitucionalidade (Ação Direta de Inconstitucionalidade, Ação Declaratória de Constitucionalidade $^{18}$ e Arguição de Descumprimento de Preceito Fundamental ${ }^{19}$ ). Isso porque, em que pese o art. 196 da Constituição determinar a concretização do direito à saúde por meio de "políticas sociais e econômicas que visem à redução do risco de doença e de outros agravos e ao acesso universal e igualitário às ações e serviços para sua promoção, proteção e recuperação", o Supremo Tribunal Federal (e também outros tribunais), por meio de controle difuso de constitucionalidade, tem interpretado que se trata de um direito individual, que pode ser usufruído diretamente por cada indivíduo, e não necessariamente pela implementação de uma política pública.

Nesse contexto, o Judiciário passou a ser um participante ativo na formulação de políticas públicas no espaço democrático, por meio do ativismo judicial em torno do direito fundamental à saúde, procurando garantir ao cidadão o seu direito constitucional frente à lentidão ou inércia do Estado em cumprir a obrigação de the oferecer o mínimo de assistência nessa área. Em linhas gerais, o que se percebe é um confronto entre a necessidade de cumprimento do direito fundamental à saúde, de um lado, e a escassez dos recursos

\footnotetext{
${ }^{17}$ BRASIL. Lei n. 8.080, de 19 de setembro de 1990. Dispõe sobre as condições para a promoção, proteção e recuperação da saúde, a organização e o funcionamento dos serviços correspondentes e dá outras providências. In: Diário Oficial da República Federativa do Brasil, Brasília, DF, 20 set. 1990. Disponível em: <http://www.planalto.gov.br/ccivil_03/leis/L8080.htm>. Acesso em: 26 jul. 2017.

${ }^{18}$ BRASIL. Lei n. 9.868, de 10 de novembro de 1999. Dispõe sobre o processo e julgamento da ação direta de inconstitucionalidade e da ação declaratória de constitucionalidade perante o Supremo Tribunal Federal. In: Diário Oficial da República Federativa do Brasil, Brasília, DF, 11 nov. 1999. Disponível em: <http://www.planalto.gov.br/ccivil_03/leis/L9868.htm>. Acesso em: 26 jul. 2017.

${ }^{19}$ BRASIL. Lei n. 9.882, de 03 de dezembro de 1999. Dispõe sobre o processo e julgamento da arguição de descumprimento de preceito fundamental, nos termos do $\S 1^{\circ}$ do art. 102 da Constituição Federal. In: Diário Oficial da República Federativa do Brasil, Brasília, DF, 6 dez. 1999. Disponível em: <http://www.planalto.gov.br/ccivil_03/leis/[9882.htm>. Acesso em: 26 jul. 2017.
} 
ISSN 1981-3694

(DOI): 10.5902/1981369429084

A JUDICIALIZACÃO DO DIREITO À SAÚDE NO

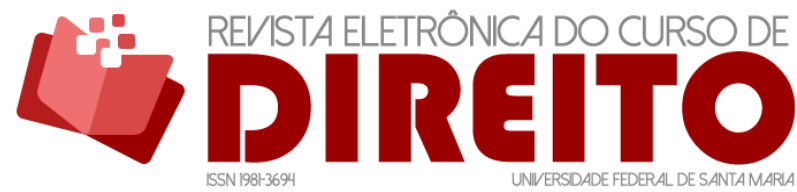
CONSTITUCIONALISMO BRASILEIRO: ESCASSEZ, CUSTOS E EFICIÊNCIA ECONÔMICO-SOCIAL

EVERTON DAS NEVES GONCALVES MARCO AURÉLIO SOUZA dA SILVA

orçamentários do Estado, de outro. Partindo-se da premissa de que os recursos na sociedade são finitos e os desejos humanos são infinitos, emerge a necessidade de realizar escolhas diante das alternativas possíveis e de se sujeitar a sacrifícios (custo de oportunidade) para a melhor alocação dos recursos.

A ideia de escassez guarda correlação com a expressão "reserva do possível"20, que significa um limite fático. Assim, é racional pensar que o cumprimento de um direito fundamental à saúde demanda a existência de recursos suficientes para o seu atendimento, de maneira que esse direito só poderá ser efetivado na medida em que exista dinheiro disponível para tanto. Conforme bem salienta Barcellos, “pouco adiantará, do ponto de vista prático, a previsão normativa ou a refinada técnica hermenêutica se absolutamente não houver dinheiro para custear a despesa gerada por determinado direito subjetivo". ${ }^{21}$

Tendo em conta a noção de que os recursos públicos são escassos, sua destinação e aplicação sempre se dará de forma seletiva (às vezes, trágica), o que implica um conflito não só entre direito e recursos escassos, mas principalmente entre direitos. Logo, perquirir acerca da ponderação entre direito fundamental à saúde e reserva do possível (ou escassez) não é de todo correto. $\mathrm{Na}$ verdade, o que se pondera é o direito fundamental à saúde individual e o direito fundamental à saúde coletiva. Vale dizer, então, que a reserva do possível é uma limitação fática de realização dos direitos fundamentais sociais que deve ser levada em consideração.

Os discursos de que os direitos sociais, notadamente os relacionados à saúde, são absolutos e de que os custos econômicos restringem direitos, não devem ser levados ao extremo. A partir das notícias veiculadas pelos meios de comunicação é possível constatar que, não raro, o Estado é mal gerido, desperdiça recursos e não investe em prevenção, como no caso da assistência à saúde. ${ }^{22}$ Também é notório que diversos entes federativos se encontram

20 De acordo com Sarlet, a construção teórica da expressão "reserva do possível” tem origem na Alemanha, a partir de 1970, em que a efetividade dos direitos sociais a prestações materiais estaria na dependência das capacidades financeiras do Estado. 0 caso paradigmático enfrentado pelo Tribunal Constitucional Federal da Alemanha versava sobre o direito de acesso ao ensino superior (a Universidade da Bavária limitara as vagas ao acesso direto de alunos ao curso de medicina, tendo em vista a capacidade de suas instalações), a partir do qual restou firmado o entendimento no sentido de que a prestação reclamada deve corresponder àquilo que o indivíduo pode razoavelmente exigir da sociedade (SARLET, Ingo Wolfgang; FIGUEIREDO, Mariana Filchtiner. Reserva do possível, mínimo existencial e direito à saúde: algumas aproximações. In: SARLET, Ingo Wolfgang; TIMM, Luciano Bentti (Org.). Direitos fundamentais: orçamento e "reserva o possível". 2. ed. rev. e ampl. Porto Alegre: Livraria do Advogado, 2013, p. 29).

${ }^{21}$ BARCELLOS, Ana Paula de. A eficácia jurídica dos princípios constitucionais: o princípio da dignidade da pessoa humana. Rio de Janeiro: Renovar, 2002, p. 236-237.

${ }_{22}$ Cumpre destacar que o orçamento do Estado de Santa Catarina relacionado à saúde é de, aproximadamente, R\$ 2 bilhões por ano, mas o Estado investe menos de $1 \%$ desse montante na manutenção da saúde (SANTA CATARINA. Tribunal de Contas. Parecer prévio sobre as contas prestadas 
ISSN 1981-3694

(DOI): $10.5902 / 1981369429084$

A JUDICIALIZAÇÃO DO DIREITO À SAÚDE NO

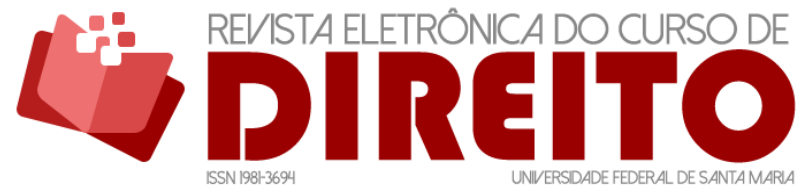
CONSTITUCIONALISMO BRASILEIRO: ESCASSEZ, CUSTOS E EFICIÊNCIA ECONÔMICO-SOCIAL

EVERTON DAS NEVES GONÇALVES MARCO AURÉLIO SOUZA dA SILVA

visivelmente em situação de descontrole financeiro, por terem feito escolhas políticas equivocadas ao longo dos últimos anos. Portanto, impõe-se diferenciar as situações em que o Estado alega não ter condições de efetivar o direito fundamental à saúde simplesmente por inexistirem recursos financeiros para o seu atendimento, porque foram bem ou eficientemente aplicados, daquelas em que os recursos não existem em razão de terem sido alocados em finalidades outras, distintas do programado (por exemplo, publicidade, propaganda, corrupção etc.). De qualquer forma, há um elemento que está presente em ambas as situações e que não pode ser ignorado - o custo dos direitos sociais.

\section{OS DIREITOS SOCIAIS TÊM CUSTOS?}

Holmes e Sunstein levantaram a discussão sobre o custo dos direitos arguindo a tese de que a eficácia dos direitos depende dos tributos. Partem de um caso concreto, ocorrido em 1995, em que um incêndio numa propriedade privada na região de Westhampton, no Estado de Nova York, produziu poucos danos materiais e nenhuma morte porque houve uma ação eficiente do corpo de bombeiros e de outros funcionários do Estado. Justificam que só foi possível fazer frente ao incêndio e defender a propriedade privada porque foram utilizados recursos públicos, aportados por todos os cidadãos, o que leva à conclusão de que os direitos não são independentes dos custos. ${ }^{23}$

Os argumentos dos citados autores são provocativos, já que a tese fundamental é de que o direito custa dinheiro (rights cost money), na medida em que não pode ser protegido ou obrigado sem suporte econômico ou financiamento público. Ao refletirem sobre a natureza dos direitos, rechaçam a distinção entre direitos positivos (prestação) e negativos (defesa), argumentando se tratar de uma falsa distinção, no sentido de que os primeiros demandariam recursos do Estado, enquanto os segundos só lhe impõem o dever de não interferir. Do mesmo modo em relação aos direitos civis e sociais, afastando a afirmação de que somente os sociais implicariam custos estatais. Portanto, não fazem distinção entre direitos positivos e negativos, assim como entre direitos civis e sociais. ${ }^{24}$

pelo Governador do Estado de Santa Catarina - exercício 2014. Florianópolis: Tribunal de Contas, 2016, p. 228).

${ }_{23}$ HOLMES, Stephen; SUNSTEIN, Cass R. The cost of rights: why liberty depends on taxes. New York: W. W. Norton \& Company, 1999, p. 13.

${ }^{24}$ HOLMES, Stephen; SUNSTEIN, Cass R. The cost of rights: why liberty depends on taxes. New York: W. W. Norton \& Company, 1999, p. 35. 
ISSN 1981-3694

(DOI): $10.5902 / 1981369429084$

A JUDICIALIZAÇÃO DO DIREITO À SAÚDE NO

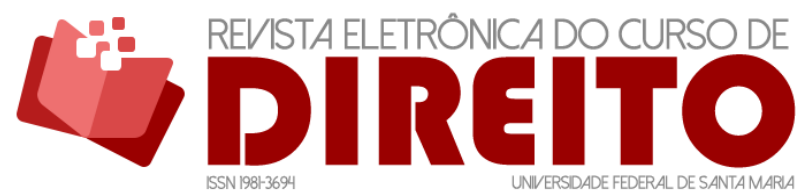
CONSTITUCIONALISMO BRASILEIRO: ESCASSEZ, CUSTOS E EFICIÊNCIA ECONÔMICO-SOCIAL

EVERTON DAS NEVES GONÇALVES MARCO AURÉLIO SOUZA dA SILVA

A ideia central é de que todos os direitos, em sentido legal (e não moral), quando são ofendidos, requerem um remédio, uma reparação, o que evidencia a inadequada distinção entre os direitos positivos e negativos. E se todos os direitos têm custos, alguém tem que pagar por eles, que é o Estado, por meio de fundos públicos, que decorrem do pagamento de tributos. Por isso, Holmes e Sunstein afirmam que todos os direitos são caros porque todos pressupõem uma máquina estatal eficaz de supervisão, financiada pelos contribuintes, para monitorar e fiscalizar. ${ }^{25}$

Outro importante argumento sobre o custo dos direitos também pode ser extraído de Posner. $\mathrm{O}$ autor enfatiza que a natureza da análise econômica é muitas vezes incompreendida, o que leva alguns leitores a rejeitar a aplicabilidade da economia ao sujeito de direitos, por acreditar que economia se refere a dinheiro e mercados, e que quando é aplicada a questões políticas e sociais, estas se reduzem a objetos de comércio. Afirma que tal visão é equivocada, ressaltando que a economia trata da gestão da escassez. Onde existe escassez, é preciso fazer concessões (trade offs), sendo a economia a ciência das concessões racionais. ${ }^{26}$

Posner salienta que os direitos jurídicos não são bens gratuitos, pois consomem recursos reais, incluindo o tempo precioso de profissionais altamente qualificados, que podem ser particularmente escassos nos países pobres. Além dos custos diretos, existem custos indiretos para que sejam executáveis os direitos. 0 autor chama a atenção para o fato de que a reflexão sobre os custos pode até auxiliar no projeto e no redesenho das instituições. ${ }^{27}$

Como se percebe a partir desses argumentos, o Estado possui o papel de manter a ordem por meio de um aparato burocrático (Poderes Executivo, Legislativo e Judiciário, instituições públicas, policiais, promotores, juízes, servidores públicos etc.) que se sustenta pelo pagamento de tributos pelos contribuintes. Sendo assim, o bem-estar coletivo e individual é promovido de maneira distributiva a partir dos recursos provenientes da tributação.

Nesse sentido, a satisfação dos direitos, especialmente os sociais, está na dependência da receita arrecadada, que envolve recursos escassos. A escassez de recursos, portanto, não pode ser ignorada na criação, na interpretação e na aplicação do direito. Denota-se, assim, que a racionalidade econômica demanda a análise de custo-benefício, de maneira que, num ambiente de escassez, o atendimento de direitos sociais pelo Estado está limitado à

${ }^{25}$ HOLMES, Stephen; SUNSTEIN, Cass R. The cost of rights: why liberty depends on taxes. New York: W. W. Norton \& Company, 1999, p. 44.

${ }^{26}$ POSNER, Richard A. The Cost of Rights: Implications for Central and Eastern Europe - And for the United States. V. 32. N. 1. Tulsa Law Journal, 1996, p. 01-02.

${ }^{27}$ POSNER, Richard A. The Cost of Rights: Implications for Central and Eastern Europe - And for the United States. V. 32. N. 1. Tulsa Law Journal, 1996, p. 02. 
disponibilidade orçamentária. Por consequência, não se podendo prestar integralmente tais direitos a todos os demandantes por falta de recursos, resta patente o direcionamento seletivo no sentido dos riscos sociais mais relevantes, priorizando os mais necessitados coletivamente e eliminando desperdícios.

Um exemplo de custos dos direitos pode ser visto no caso da concessão de medicamentos. 0 gasto do governo federal com a compra de medicamentos por determinação da Justiça tem crescido vertiginosamente. Em 2010, foi de R\$ 122 milhões; em 2011, de R\$ 230 milhões; em 2012, de R\$ 367 milhões; em 2013, de R\$ 549 milhões; em 2014, de R\$ 839 milhões; em 2015, de R\$ 1,1 bilhão e, em 2016, de R\$ 1,6 bilhão. Um crescimento em 2016, comparado com 2010, de mais de $1.233 \%{ }^{28}$ A previsão de despesas com determinações judiciais de atendimento à saúde envolvendo a União, os Estados e os Municípios é de R\$ 7 bilhões, somente neste ano de $2017 .{ }^{29}$

Essa é a situação por que passa a concretização do direito à saúde no país, em que a judicialização muitas vezes desconsidera que a satisfação desse direito possui limites no orçamento do ente federado, em face dos custos que apresenta, bem como não leva em conta que o efeito desalocativo dos recursos se dá de forma imprevisível, alterando de forma abrupta o que foi previamente programado pelo administrador, eleito pela vontade popular e por seu programa de governo. Nesse cenário, convém cotejar a eficiência com o reflexo social, conforme se extrai do conteúdo do Princípio da Eficiência Econômico-Social (PEES).

\section{PRINCÍPIO DA EFICIÊNCIA ECONÔMICO-SOCIAL (PEES)}

A doutrina econômica possui como um de seus principais pressupostos a eficiência, que pode ser conceituada de diversas formas, conforme seja o modelo teórico empregado ${ }^{30}$. De modo

${ }^{28}$ COLLUCCI, Cláudia. SP cede à União “detector” de fraude em ações por medicamentos. Cotidiano. Folha de S. Paulo. 21 de julho de 2017. Disponível em: <http:// www1.folha.uol.com.br/cotidiano/2017/07/1903086-sp-cede-a-uniao-detector-de-fraude-emacoes-por-medicamentos.shtml>. Acesso em: 17 ago. 2017.

${ }^{29}$ BRASIL. Conselho Nacional de Justiça. CNJ avança para qualificar decisões judiciais sobre gastos com saúde. Disponível em: <http://www.cnj.jus.br/noticias/cnj/84486-cnj-avanca-na-qualificacao-dajudicializacao-para-otimizar-gasto-de-saude>. Acesso em: 24 ago. 2017.

${ }^{30} \mathrm{Na}$ doutrina, pelo menos três acepções de eficiência são bastante destacadas - a de Coase, a de Pareto e a de Kaldor-Hicks. A eficiência alocativa de Coase pode ser resumida no fato de que o máximo uso produtivo dos recursos não depende da atribuição inicial dos direitos, sendo esta apenas o ponto de partida a partir do qual as negociações começam. O ponto em que as negociações cessam representa a alocação eficiente de recursos. O modelo teórico de Pareto concebe uma situação como eficiente quando 
geral, o termo "eficiência" é utilizado no sentido da obtenção do máximo de benefícios com o mínimo de custos. Em outras palavras, trata-se da otimização ou maximização de alguma medida de valor para satisfação de necessidades, considerando que o indivíduo tem preferências entre as coisas que busca, a fim de satisfazer os seus desejos.

Procurando traçar um novo arranjo entre direito e economia, tomando por base a realidade brasileira e buscando uma convergência entre questões distributivas e sociais, Gonçalves e Stelzer desenvolvem o denominado Princípio da Eficiência Econômico-Social $(P E E S)^{31}$. Tal princípio conclama a aplicação da eficiência dentro de limites determinados pelo Estado e orientados pelo Mínimo Ético Legal (MEL), pois ponderam que a análise econômica de custos e benefícios, que considera essencialmente critérios distributivos, tende a promover maiores lucros a determinados grupos de pessoas em detrimento da carência de outros, assim como a desconsideração da eficiência na tomada de decisão tende a produzir injustiças.

Sob a égide do PEES, devem ser considerados os critérios progressistas de distribuição de riqueza no âmbito do processo de tomada de decisão. Nesse cenário, aproveita-se o critério de eficiência de Kaldor-Hicks para a adjudicação do direito, incluindo no cálculo decisório as políticas distributivas e as externalidades negativas e positivas. 0 mencionado princípio concebe uma intervenção estatal por meio da regulação da atividade econômica, com o escopo de eliminação do desequilíbrio social a partir da obrigação de compensação dos desfavorecidos e de normas eficientes. Nas palavras de Gonçalves e Stelzer, cuida-se da elaboração e aplicação da norma de forma economicamente eficiente, maximizando-se resultados esperados quando da adjudicação de direitos ou da determinação de obrigações, conforme caráter recíproco das

não for possível melhorar a posição de uma das partes sem piorar a de outra. Já o modelo de Kaldor-Hicks surgiu com a intenção de melhorar o critério de Pareto, baseando-se na premissa de que uma situação será eficiente quando, ainda que uma das partes envolvidas tenha a sua situação piorada, haja a possibilidade de compensá-la. Por esse critério, o importante é que os ganhadores possam potencialmente compensar os perdedores, ainda que efetivamente não o façam.

${ }^{31}$ GONÇALVES, Everton das Neves; STELZER, Joana. O Princípio da Eficiência Econômico-Social no Direito Brasileiro: a tomada de decisão normativo-judicial. Sequencia. V. 35, n. 68. Florianópolis, SC. 2014, p. 261-290. Ver também dos mesmos autores: GONCALVES, Everton das Neves. Eficiência e Direito: pecado ou virtude, uma incursão pela Análise Econômica do Direito. Revista Jurídica da Faculdade de Direito do UNICURITIBA. Curitiba-PR: Unicuritiba. Revista Eletrônica, v. 1, n. 28, p. 77-122, 2012. Disponível em: <http://revista.unicuritiba.edu.br/index.php/RevJur/article/view/412/317>. Acesso em: 08 ago. 2017; GONCALVES, Everton das Neves. A tomada de decisão normativo-judicial segundo o Princípio da Eficiência Econômico-Social (PEES). In: POMPEU, Gina Vidal Marcílio; PINTO, Felipe Chiarello de Souza; CLARK, Giovani (Orgs.). Direto e Economia. XXII CONPEDI. São Paulo-SP, p. 319-346; GONCCALVES, Everton das Neves. 0 viés econômico do direito justo e eficiente: 0 princípio da eficiência econômico-social. In: OPUSZKA, Paulo Ricardo; SÉLLOS-KNOERR, Viviane Coêlho (Orgs.). Revista Jurídica do Unicuritiba. v. 3, n. 32, p. 128-162. <http://revista.unicuritiba.edu.br/index.php/RevJur/article/view/682>. Acesso em: 08 ago. 2017. 
ISSN 1981-3694

(DOI): $10.5902 / 1981369429084$

A JUDICIALIZAÇÃO DO DIREITO À SAÚDE NO

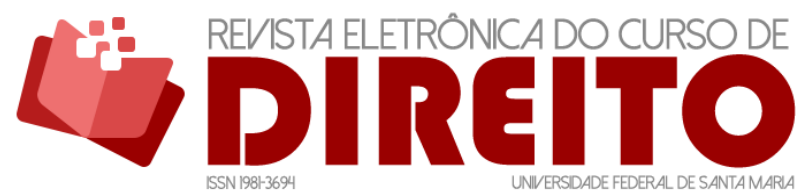
CONSTITUCIONALISMO BRASILEIRO: ESCASSEZ, CUSTOS E EFICIÊNCIA ECONÔMICO-SOCIAL

EVERTON DAS NEVES GONÇALVES MARCO AURÉLIO SOUZA dA SILVA

ações e interesses, porém, considerando o reflexo social e o custo externo imposto à sociedade. ${ }^{32}$

O PEES constitui um instrumento interessante para a adjudicação eficiente dos direitos, especialmente em um país como Brasil, de enormes desigualdades sociais, na medida em que procura garantir a racionalidade econômica levando em conta o reflexo social, isto é, os custos sociais resultantes das externalidades. Não é por outra razão que considera no cálculo econométrico as variáveis de cunho social, as quais devem ser internalizadas pelas partes.

Importante notar que, sob o aspecto econômico-pragmático, a ideia de justiça deve ser alcançada pela composição ideal das partes. Para tanto, a tomada de decisão sob a orientação do PEES deve levar em conta os seguintes elementos indissociáveis: a) a inclusão do maior número de variáveis no cálculo econométrico de custo e benefício para a tomada de decisão econômico-jurídica; b) a consideração, para fins de cálculo e distribuição de benefícios ou imposição de custos, da totalidade dos agentes econômicos e das partes envolvidas, ou que venham a sofrer reflexos em virtude da tomada de decisão econômico-jurídica; c) o primado da distribuição e redistribuição dos escassos recursos em função da eficiência econômico-social, segundo o Mínimo Ético Legal determinado pelo Estado; d) a apreciação do caso concreto de forma eficiente, segundo expectativas da análise econômica do direito, eliminando-se os reflexos das externalidades individuais ou coletivas que venham a determinar injustificáveis custos sociais, bem como os reflexos da ação presente com relação às gerações futuras; e e) a avaliação dos resultados do sistema jurídico e de sua concreta aplicação a partir da consideração dos incentivos indutores ou obstantes da ação social. ${ }^{33}$

Não é demais lembrar que o termo "eficiência" foi acrescido pelo Poder Constituinte Derivado Reformador ao art. 37, caput, da Constituição Federal, quando da edição da Emenda Constitucional n. 19/1998, consagrando-o como princípio constitucional, ao lado de outros igualmente importantes, a ser observado não apenas pela Administração Pública como, também, pelo Poder Judiciário na fundamentação de suas decisões.

Portanto, o PEES se alinha tanto ao paradigma da análise econômica do direito, no intuito de promover a fluidez das relações de produção, a maximização da riqueza e a inclusão social no cálculo econômico, quanto ao preceito contido no art. 37, caput, da Constituição

32 GONÇALVES, Everton das Neves e STELZER, Joana. O Princípio da Eficiência Econômico-Social no Direito Brasileiro: a tomada de decisão normativo-judicial. Sequencia. V. 35, n. 68. Florianópolis, SC. 2014, p. 273.

33 GONÇALVES, Everton das Neves e STELZER, Joana. O Princípio da Eficiência Econômico-Social no Direito Brasileiro: a tomada de decisão normativo-judicial. Sequencia. V. 35, n. 68. Florianópolis, SC. 2014, p. 274-275. 
ISSN 1981-3694

(DOI): $10.5902 / 1981369429084$

A JUDICIALIZAÇÃO DO DIREITO À SAÚDE NO

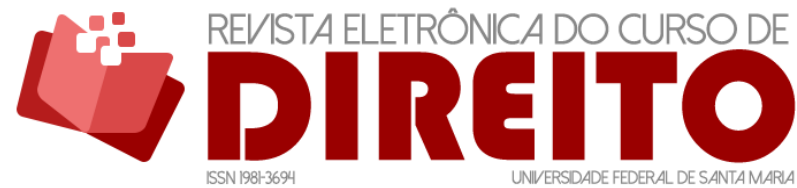
CONSTITUCIONALISMO BRASILEIRO: ESCASSEZ, CUSTOS E EFICIÊNCIA ECONÔMICO-SOCIAL

EVERTON DAS NEVES GONÇALVES MARCO AURÉLIO SOUZA dA SILVA

Federal, que busca a concretização das finalidades da Administração Pública sem desperdícios de recursos. Nesse contexto, entende-se perfeitamente aplicável o princípio aos casos de judicialização da saúde.

\section{O CONSELHO NACIONAL DE JUSTIÇA E A BUSCA DE MAIOR EFICIÊNCIA NA SOLUÇÃO DAS DEMANDAS JUDICIAIS}

A judicialização das políticas públicas de saúde tem crescido vertiginosamente, impactando de forma negativa os orçamentos dessa área. Tal situação tem exigido um esforço multidisciplinar no sentido de encontrar mecanismos que promovam a sustentabilidade jurídica, econômica e social do Sistema Único de Saúde (SUS).

Sensível à demanda que envolve o Poder Público e o Poder Judiciário, especialmente, o Conselho Nacional de Justiça (CNJ) editou a Recomendação n. 31/2010 ${ }^{34}$, a fim de que os Tribunais adotassem medidas que pudessem subsidiar os magistrados e os operadores do direito na busca de maior eficiência na solução das demandas judiciais em torno da assistência à saúde. Com a Resolução n. 107/2010 35 , criou o Fórum Nacional do Judiciário para o monitoramento e resolução das demandas nessa área, que culminou com a instituição dos Comitês Executivos Estaduais, com o objetivo de coordenar e executar ações específicas.

Seguindo esse propósito, foi criado em 2012 o Comitê Estadual de Monitoramento e Resolução de Demandas de Assistência da Saúde de Santa Catarina (COMESC). O comitê é integrado por representantes da Justiça Federal e Estadual, Ministério Público Federal e Estadual, Ordem do Advogados do Brasil, Tribunal de Contas do Estado, Secretarias de Saúde do Estado e de Florianópolis, Conselho de Secretarias Municipais de Saúde, Defensoria Pública da União e do Estado, Federação Catarinense de Municípios, Conselho Municipal de Saúde de Florianópolis, Conselhos Regionais de Classe e outros segmentos do Poder Público, da sociedade civil e de comunidades interessadas que, voluntariamente, cumulam essa atividade com os seus

\footnotetext{
${ }^{34}$ BRASIL. Conselho Nacional de Justiça. Recomendação n. 31/2010, de 30 de março de 2010. Recomenda aos Tribunais a adoção de medidas visando a melhor subsidiar os magistrados e demais operadores do direito, para assegurar maior eficiência na solução das demandas judiciais envolvendo a assistência à saúde. Disponível em: <http://www.cnj.jus.br/busca-atos-adm?documento=1195>. Acesso em: 12 ago. 2017.

${ }^{35}$ BRASIL. Conselho Nacional de Justiça. Resolução n. 107/2010, de 06 de abril de 2010. Institui o Fórum Nacional do Judiciário para monitoramento e resolução das demandas de assistência à saúde. Disponível em: <http://www.cnj.jus.br/busca-atos-adm?documento=2831>. Acesso em: 12 ago. 2017.
} 
ISSN 1981-3694

(DOI): $10.5902 / 1981369429084$

A JUDICIALIZACÃ̃O DO DIREITO À SAÚDE NO

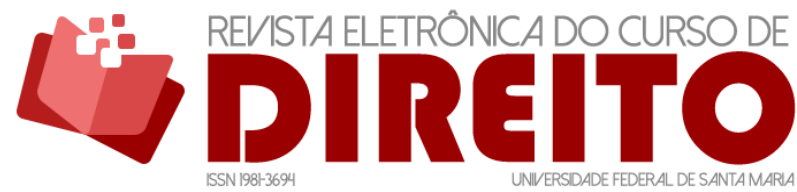
CONSTITUCIONALISMO BRASILEIRO: ESCASSEZ, CUSTOS E EFICIÊNCIA ECONÔMICO-SOCIAL

EVERTON DAS NEVES GONCALVES MARCO AURÉLIO SOUZA dA SILVA

respectivos trabalhos. 0 papel do COMESC é monitorar os fatores envolvidos nas ações judiciais e buscar a solução dos conflitos na área da saúde.

No âmbito das reuniões do comitê são promovidos debates articulados com vistas à elaboração de enunciados e recomendações, disponibilizados publicamente em seu sítio eletrônico ${ }^{36}$, sobre temas comuns nas ações judiciais, buscando uniformizar procedimentos a serem adotados pelos profissionais de saúde e do direito, bem como priorizando a assistência à saúde, a organização do SUS e o desenvolvimento das políticas públicas para os destinatários do sistema.

Em 2015, o CNJ publicou uma pesquisa sobre o tema, realizada pela Universidade do Estado do Rio de Janeiro (UERJ) ${ }^{37}$. Os resultados evidenciaram que: a) as demandas judiciais versavam de forma predominante sobre aspectos curativos da saúde (medicamentos, tratamentos, próteses etc.) e pouco sobre aspectos preventivos (vacinas, exames etc.); b) a litigância era predominantemente individual; c) na maioria dos casos havia deferimento do pedido com antecipação de tutela, sem pedido de informações complementares, na primeira instância e confirmada na segunda; d) a maioria das decisões pesquisadas não citava ou tomava como referência a audiência pública do STF de 2009, as contribuições do CNJ pelas recomendações, nem o Fórum Nacional e os comitês estaduais; e) a maioria das decisões não mencionava os Núcleos de Apoio Técnico (NAT) como estratégia para a atividade judicante em saúde, apesar de se observar nos dados uma tendência de sua utilização, especialmente nas capitais. Em 2016, o CNJ editou a Portaria n. 08/2016 $6^{38}$, instituindo o Comitê Organizador do Fórum Nacional do Poder Judiciário para monitoramento e resolução das demandas de assistência à saúde.

Vale registrar, ainda, que os magistrados de todas as regiões de Santa Catarina contarão com o apoio de técnicos especializados em saúde nas ações judiciais que envolvam o fornecimento de medicamentos por parte do Estado. Todas as comarcas catarinenses deverão

\footnotetext{
${ }^{36}$ SANTA CATARINA. Comitê Estadual de Monitoramento e Resolução das Demandas de Assistência da Saúde de Santa Catarina - COMESC. Disponível em: <http:/ / portalses.saude.sc.gov.br/index.php?option=com_content\&view=article\&id=4949\&ltemid=668>. Acesso em: 12 ago. 2017.

${ }^{37}$ Para mais detalhes, ver: BRASIL. Conselho Nacional de Justiça. Justiça Pesquisa: judicialização da saúde no Brasil - dados e experiências. Brasília: Conselho Nacional de Justiça, 2015. Disponível em: <http://www.cnj.jus.br/files/conteudo/destaques/arquivo/2015/06/6781486daef02bc6ec8c1e491a56500 6.pdf>. Acesso em: 20 ago. 2017.

${ }^{38}$ BRASIL. Conselho Nacional de Justiça. Portaria n. 08/2016, de 02 de fevereiro de 2016. Cria o Comitê Organizador do Fórum Nacional do Poder Judiciário para monitoramento e resolução das demandas de assistência à saúde. Disponível em: <http://www.cnj.jus.br/files/conteudo/arquivo/2016/07/7416acb59c746525fd9f278a5d7719b9.pdf>. Acesso em: 12 ago. 2017.
} 
ISSN 1981-3694

(DOI): $10.5902 / 1981369429084$

A JUDICIALIZAÇÃO DO DIREITO À SAÚDE NO

contar, até o final de 2018, com o atendimento do Núcleo de Apoio Técnico (NAT), da Secretaria Estadual da Saúde. O Núcleo subsidia os juízes com informações sobre medicamentos padronizados, tratamentos mais adequados para cada caso e, eventualmente, a necessidade de mais dados por parte do paciente para instruir mais adequadamente o pedido feito na Justiça.

Como se percebe, é notória a gravidade do ponto a que chegou a judicialização da saúde no Brasil. De certa forma, parece haver um consenso de que as políticas públicas de saúde, em particular, devem ser abordadas a partir do campo interdisciplinar, ocasião em que o direito, a economia e a medicina ocupam um lugar de proeminência.

\section{UM CASO CONCRETO PARA PENSAR NOS CUSTOS DO DIREITO FUNDAMENTAL À SAÚDE}

Um exemplo das consequências da atuação do Poder Judiciário sobre questões políticas pode ser vista na decisão proferida pelo Grupo de Câmaras de Direito Público do Tribunal de Justiça de Santa Catarina, em 09.11.2016, diga-se, de passagem, a primeira no País em sede de Incidente de Resolução de Demandas Repetitivas (IRDR) ${ }^{39}$ sobre concessão de medicamentos e que passou a servir de parâmetro para os demais casos envolvendo a matéria no Estado.

O caso julgado se refere a um paciente que acionou o Poder Judiciário objetivando que o Estado de Santa Catarina e o Município de Agronômica fornecessem medicamentos em razão de não poder arcar com os custos do tratamento. A controvérsia posta nos autos dizia respeito à necessidade ou não de comprovação da carência de recursos ou hipossuficiência financeira do cidadão nas ações voltadas a exigir prestação positiva do Estado em matéria de medicamentos, cirurgia e demais procedimentos afetos à saúde pública.

O Estado sustentou a tese da imprescindibilidade da demonstração de carência financeira do requerente e de seu ente familiar, com amparo nos princípios da eficiência na gestão do dinheiro público e da razoabilidade, sob o argumento de que deve ser priorizada a destinação dos escassos recursos públicos às pessoas realmente necessitadas. Por meio de sua Consultoria Jurídica, a Secretaria de Estado da Saúde de Santa Catarina informou nos autos que no ano de 2015 foram gastos mais de R\$ 150 milhões para atender pouco mais de 30 mil pacientes em razão de medidas judiciais, a um custo médio de R\$ 5 mil por pessoa. No ano de

39 SANTA CATARINA. Tribunal de Justiça de Santa Catarina. Incidente de Resolução de Demandas Repetitivas n. 0302355-11.2014.8.24.0054/50000. Rio do Sul. Rel.: Des. Ronei Danielli. Julg.: 09 nov. 2016. 
2014 houve gastos públicos de aproximadamente R\$ 156 milhões para o cumprimento das ordens judiciais em favor de pouco mais do que 26 mil pacientes, sendo que esse montante seria suficiente para manter dois dos hospitais sob a administração da Secretaria Estadual de Saúde (Hospital Celso Ramos e Hospital Nereu Ramos) por quase um ano, viabilizando o atendimento de cerca de 195 mil pessoas. Destacou, ainda, que a quantia destinada aos 26 mil pacientes judiciais em 2014 asseguraria, por dois meses, a manutenção de todos os 13 (treze) hospitais administrados diretamente pela Secretaria da Saúde, beneficiando mais de 170 mil pessoas. Vale acrescentar que o orçamento do Estado de Santa Catarina para a saúde gira em torno de R\$ 2 bilhões por ano. ${ }^{40}$

Por maioria, o Grupo de Câmaras julgou o Incidente de Resolução de Demandas Repetitivas firmando as seguintes teses jurídicas:

1) Para a concessão judicial de remédio ou tratamento constante do rol do SUS, devem ser conjugados os seguintes requisitos: a) a necessidade do fármaco perseguido e adequação à enfermidade apresentada, atestada por médico; b) a demonstração, por qualquer modo, de impossibilidade ou empecilho à obtenção pela via administrativa (Tema 350 do STF).

2) Para a concessão judicial de fármaco ou procedimento não padronizado pelo SUS, são requisitos imprescindíveis: a) a efetiva demonstração de hipossuficiência financeira; b) ausência de política pública destinada à enfermidade em questão ou sua ineficiência, somada à prova da necessidade do fármaco buscado por todos os meios, inclusive mediante perícia médica; c) nas demandas voltadas aos cuidados elementares à saúde e à vida, ligando-se à noção de dignidade humana (mínimo existencial), dispensam-se outras digressões; d) nas demandas claramente voltadas à concretização do máximo desejável, faz-se necessária a aplicação da metodologia da ponderação dos valores jusfundamentais, sopesando-se eventual colisão de princípios antagônicos (proporcionalidade em sentido estrito) e circunstâncias fáticas do caso concreto (necessidade e adequação), além da cláusula da reserva do possível.

Não obstante o bem lançado fundamento pelo relator no voto condutor da decisão, efetuando a ponderação entre a efetivação do direito e a reserva do possível apenas quando o medicamento ou tratamento não estiver na listagem oficial do SUS, ainda que mantidos esses parâmetros, o equilíbrio orçamentário poderá ser afetado se houver grande demanda de medicamentos protocolares. Afinal, se o acesso a medicamentos e tratamentos públicos for irrestrito, beneficiando qualquer pessoa, ainda que em condições de hipossuficiência, o orçamento irá sucumbir em prejuízo de todos, especialmente daqueles mais pobres.

Outra questão importante, merece ser destacada. O julgamento do incidente, ao delimitar os critérios dividindo-os entre concessão judicial de medicamentos constantes e não

\footnotetext{
${ }^{40}$ SANTA CATARINA. Tribunal de Contas. Parecer prévio sobre as contas prestadas pelo Governador do Estado de Santa Catarina - exercício 2014. Florianópolis: Tribunal de Contas, 2016, p. 225.
} 
ISSN 1981-3694

(DOI): $10.5902 / 1981369429084$

A JUDICIALIZAÇÃO DO DIREITO À SAÚDE NO

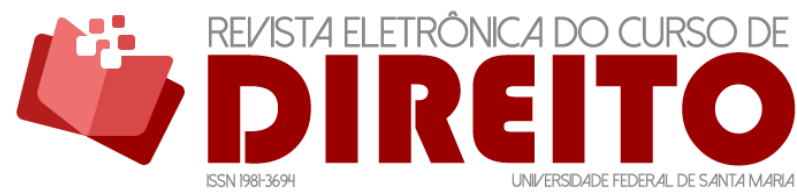
CONSTITUCIONALISMO BRASILEIRO: ESCASSEZ, CUSTOS E EFICIÊNCIA ECONÔMICO-SOCIAL

EVERTON DAS NEVES GONÇALVES MARCO AURÉlIO SOUZA dA SILVA

constantes do rol do SUS, acabou por defender que no primeiro caso o direito fundamental à saúde é absoluto e indisponível, enquanto no segundo é relativizado pela reserva do possível. Tal situação coloca um paradoxo na concretização do direito pelo Estado, criando indivíduos com direito absoluto à saúde e indivíduos com direito relativo. Mais do que isso, reconhece que alguns ganharão, sem se importar com os que irão perder, simplesmente a partir de uma dogmática que considera apenas as regras jurídicas, sem olhar para a realidade social.

Desse modo, em que pese os parâmetros fixados na decisão para a concessão de medicamentos e tratamentos pelo Estado Catarinense, permanece o conflito distributivo decorrente da relação entre receita (arrecadação) e despesa (gasto) pública na concretização do direito social à saúde. Não se deve perder de vista que os recursos públicos que financiam o fornecimento de medicamentos e tratamentos são obtidos por meio da cobrança de tributos. Embora seja atraente sustentar o discurso do direito absoluto à saúde, cabendo ao Estado fornecer todo e qualquer medicamento ou tratamento, a verdade é que se torna um argumento falacioso porque os recursos orçamentários são limitados, as necessidades humanas infinitas e o avanço tecnológico na medicina corre a passos largos, exigindo novas demandas a preços cada vez mais altos.

Sob essa visão, o Judiciário está apenas tentando equacionar um problema por meio da desqualificação dos aspectos econômicos, que por sua vez só são lembrados pelo Executivo na hora de se defender nas demandas judiciais. Nesse caso, caberia ao próprio Executivo, juntamente com o Legislativo, traçar as balizas ao acesso a medicamentos e tratamentos fornecidos na rede pública. No final das contas, o direito à saúde deveria ser concretizado independentemente de constar o tratamento ou o medicamento em listagens oficiais, simplesmente por ser um direito fundamental. Ocorre que esse direito tem um custo, limitado pela previsão orçamentária, situação que demanda também uma análise econômica do direito pleiteado.

\section{CONCLUSÃO}

Conforme se verificou ao longo do estudo, o problema relacionado aos limites da obrigação judicial de o ente federativo custear irrestritamente tratamento ou medicamento para pessoas hipossuficientes esbarra na escassez dos recursos orçamentários do Estado, além de afrontar a ideia de separação dos poderes, privilegiar o atendimento individual em detrimento do coletivo, produzindo reflexos irreparáveis no Poder Executivo, no que respeita ao 
ISSN 1981-3694

(DOI): $10.5902 / 1981369429084$

A JUDICIALIZAÇÃO DO DIREITO À SAÚDE NO

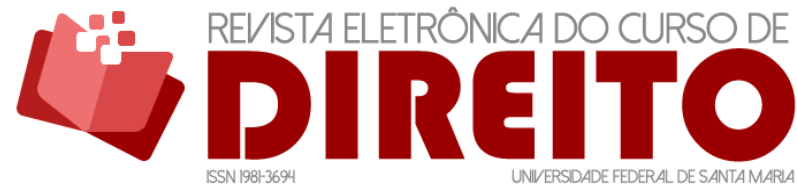
CONSTITUCIONALISMO BRASILEIRO: ESCASSEZ, CUSTOS E EFICIÊNCIA ECONÔMICO-SOCIAL

EVERTON DAS NEVES GONÇALVES MARCO AURÉlIO SOUZA dA SILVA

desequilíbrio de suas contas, de forma imprevisível e não programada, e à liberalidade de alocação de recursos por parte do administrador público. A judicialização do direito à saúde também afeta os princípios da universalidade, equidade e integralidade do atendimento.

Ficou demonstrado que a Constituição de 1988, seguindo o movimento internacional, inaugurou uma nova fase do constitucionalismo brasileiro, notadamente quando atribuiu ao Estado o papel central de promotor da transformação social por meio de prestações positivas, veiculadas por políticas públicas que assegurem direitos fundamentais individuais e sociais. Atribuiu também ao Poder Judiciário a possibilidade de promover transformações sociais no vácuo omissivo do Poder Legislativo, que tem sido visto na prática como ativismo judicial. Em meio a essa discutível legitimidade democrática de sua atividade, quando não vê limites em seu ativismo (contramajoritário) para intervir em questões nitidamente políticas (majoritárias), como a do direito à saúde, o Poder Judiciário acaba por interferir na administração dos recursos públicos pelo Executivo, transformando-se em verdadeiro “ordenador de despesas públicas".

A questão da escassez dos recursos públicos conduz à inegável conclusão de que a realização do direito social à saúde apresenta custos econômicos (que remete à ideia de custo dos direitos), vez que esse direito constitucional deve ser concretizado em consonância com as disponibilidades orçamentárias. Partindo da premissa de que todos os direitos têm custos, alguém tem que pagar por eles. No caso do Estado, isso se dá por meio da arrecadação de tributos pagos pelos contribuintes. Logo, a satisfação dos direitos sociais está na dependência da receita arrecadada, que envolve recursos escassos ou limitados à disponibilidade orçamentária. Por consequência, a prestação de saúde deve se dar por políticas públicas (coletivas), e não de forma isolada (individuais), já que o Estado se obriga a tratar igualmente todos os cidadãos. Não pode, discriminadamente, dar a um o que não pode dar a todos. Nesse viés, torna-se importante levar em consideração o Princípio da Eficiência Econômico-Social (PEES) para a adjudicação eficiente dos direitos, especialmente em um País de enormes desigualdades, incluindo no cálculo econométrico as variáveis de cunho social, que devem ser internalizadas pelas partes envolvidas.

Através do caso julgado no IRDR pelo Tribunal de Justiça de Santa Catarina, é possível antever que as teses levantadas, ainda que respeitáveis, não solucionam o problema, deixando a descoberto o problema central - o orçamento deve encontrar seus limites na atenção da coletividade. Se o acesso a medicamentos e tratamentos públicos for irrestrito, beneficiando qualquer pessoa, ainda que em condições de hipossuficiência, o orçamento irá sucumbir em prejuízo de todos, especialmente daqueles mais pobres. 
ISSN 1981-3694

(DOI): $10.5902 / 1981369429084$

A JUDICIALIZAÇÃO DO DIREITO À SAÚDE NO

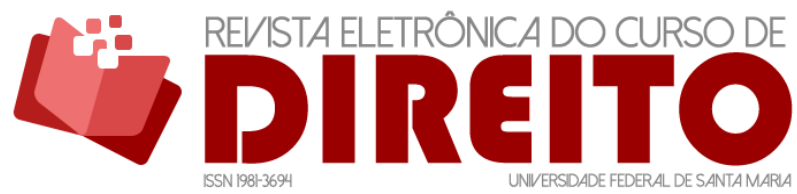
CONSTITUCIONALISMO BRASILEIRO: ESCASSEZ, CUSTOS E EFICIÊNCIA ECONÔMICO-SOCIAL

EVERTON DAS NEVES GONÇALVES MARCO AURÉLIO SOUZA dA SILVA

É claro que o Poder Judiciário não deve ser simplesmente execrado por este tipo de atuação, vez que está também apenas tentando equacionar um problema que deveria ser resolvido no âmbito da política. O papel do juiz no processo de judicialização do direito à saúde é essencial para garantir ao cidadão o seu direito constitucional, especialmente naqueles casos em que o Estado não cumpre a sua obrigação constitucional de oferecer o mínimo de assistência. No entanto, também deve ser reconhecido que o aumento da judicialização desestrutura as contas públicas e o planejamento de gastos dos entes federados, por conta do impacto desalocativo de recursos previstos anteriormente para outra finalidade.

Vale frisar, por fim, que caberia ao próprio Executivo, juntamente com o Legislativo, traçar as balizas ao acesso a medicamentos e tratamentos fornecidos na rede pública, inclusive considerando a possibilidade de previsão de incentivos fiscais, por exemplo, às empresas que se propusessem a custear tais despesas, desonerando total ou parcialmente o Estado. De outra parte, isso também seria mais facilmente alcançado se houvesse o compromisso político de construção de uma ordem econômica justa, competitiva e eficiente, um sistema tributário equitativo, combate à sonegação, à economia informal e à concorrência desleal. Parece que o caminho para a solução mais eficiente na questão da judicialização da saúde já foi dado, especialmente por parte do Conselho Nacional de Justiça (CNJ).

\section{REFERÊNCIAS}

ALEXY, Robert. Teoria dos direitos fundamentais. 2. ed. São Paulo: Malheiros Editores, 2011.

ARAUJO, Cícero. O processo constituinte brasileiro, a transição e o poder constituinte. Lua Nova. v. 88, 2013.

BARCELLOS, Ana Paula de. A eficácia jurídica dos princípios constitucionais: o princípio da dignidade da pessoa humana. Rio de Janeiro: Renovar, 2002.

BARROSO, Luís Roberto. A razão sem voto: o Supremo Tribunal Federal e o governo da maioria. In: SARMENTO, Daniel (Coord.). Jurisdição constitucional e política. Rio de Janeiro: Forense, 2015.

BRASIL. Conselho Nacional de Justiça. CNJ avança para qualificar decisões judiciais sobre gastos com saúde. Disponível em: http: / /www.cnj.jus.br/noticias/cnj/84486-cnj-avanca-naqualificacao-da-judicializacao-para-otimizar-gasto-de-saude. Acesso em: 24 ago. 2017.

BRASIL. Conselho Nacional de Justiça. Justiça Pesquisa: judicialização da saúde no Brasil - dados e experiências. Brasília: Conselho Nacional de Justiça, 2015. Disponível em:

http://www.cnj.jus.br/files/conteudo/destaques/arquivo/2015/06/6781486daef02bc6ec8c1e49 1a565006.pdf. Acesso em: 20 ago. 2017. 
BRASIL. Conselho Nacional de Justiça. Portaria n. 08/2016, de 02 de fevereiro de 2016. Cria o Comitê Organizador do Fórum Nacional do Poder Judiciário para monitoramento e resolução das demandas de assistência à saúde. Disponível em:

http://www.cnj.jus.br/files/conteudo/arquivo/2016/07/7416acb59c746525fd9f278a5d7719b9.p df. Acesso em: 12 ago. 2017.

BRASIL. Conselho Nacional de Justiça. Recomendação n. 31/2010, de 30 de março de 2010. Recomenda aos Tribunais a adoção de medidas visando a melhor subsidiar os magistrados e demais operadores do direito, para assegurar maior eficiência na solução das demandas judiciais envolvendo a assistência à saúde. Disponível em: http://www.cnj.jus.br/busca-atosadm?documento=1195. Acesso em: 12 ago. 2017.

BRASIL. Conselho Nacional de Justiça. Resolução n. 107/2010, de 06 de abril de 2010. Institui o Fórum Nacional do Judiciário para monitoramento e resolução das demandas de assistência à saúde. Disponível em: http://www.cnj.jus.br/busca-atos-adm?documento=2831. Acesso em: 12 ago. 2017.

BRASIL. Lei n. 8.080, de 19 de setembro de 1990. Dispõe sobre as condições para a promoção, proteção e recuperação da saúde, a organização e o funcionamento dos serviços correspondentes e dá outras providências. In: Diário Oficial da República Federativa do Brasil, Brasília, DF, 20 set. 1990. Disponível em: http://www.planalto.gov.br/ccivil_03/leis/L8080.htm. Acesso em: 26 jul. 2017.

BRASIL. Lei n. 9.868, de 10 de novembro de 1999. Dispõe sobre o processo e julgamento da ação direta de inconstitucionalidade e da ação declaratória de constitucionalidade perante o Supremo Tribunal Federal. In: Diário Oficial da República Federativa do Brasil, Brasília, DF, 11 nov. 1999. Disponível em: http://www.planalto.gov.br/ccivil_03/leis/L9868.htm. Acesso em: 26 jul. 2017.

BRASIL. Lei n. 9.882, de 03 de dezembro de 1999. Dispõe sobre o processo e julgamento da arguição de descumprimento de preceito fundamental, nos termos do $\S 1^{\circ}$ do art. 102 da Constituição Federal. In: Diário Oficial da República Federativa do Brasil, Brasília, DF, 6 dez. 1999. Disponível em: http://www.planalto.gov.br/ccivil_03/leis/19882.htm. Acesso em: 26 jul. 2017.

BUCCI, Maria Paula Dallari. O conceito de política pública em direito. In: BUCCI, Maria Paula Dallari (Org.). Políticas públicas: reflexões sobre o conceito jurídico. São Paulo: Saraiva, 2006.

COLLUCCI, Cláudia. SP cede à União “detector” de fraude em ações por medicamentos.

Cotidiano. Folha de S. Paulo. 21 de julho de 2017. Disponível em:

http: / / www1.folha.uol.com.br/cotidiano/2017/07/1903086-sp-cede-a-uniao-detector-defraude-em-acoes-por-medicamentos.shtml. Acesso em: 17 ago. 2017.

ELSTER, Jon. Forças e mecanismos no processo de elaboração da Constituição, in BIGONHA, Antonio Carlos Alpino; MOREIRA, Luiz (orgs). Limites do Controle de Constitucionalidade. Rio de Janeiro: Lumen Juris, 2009. 
ISSN 1981-3694

(DOI): $10.5902 / 1981369429084$

A JUDICIALIZAÇÃO DO DIREITO À SAÚDE NO

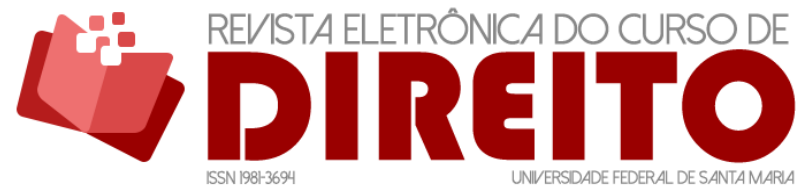
CONSTITUCIONALISMO BRASILEIRO: ESCASSEZ, CUSTOS E EFICIÊNCIA ECONÔMICO-SOCIAL

EVERTON DAS NEVES GONÇALVES MARCO AURÉLIO SOUZA DA SILVA

GONÇALVES, Everton das Neves; STELZER, Joana. O Princípio da Eficiência Econômico-Social no Direito Brasileiro: a tomada de decisão normativo-judicial. In: Sequencia. V. 35, n. 68.

Florianópolis, SC. 2014.

GONÇALVES, Everton das Neves. Eficiência e Direito: pecado ou virtude, uma incursão pela Análise Econômica do Direito. Revista Jurídica da Faculdade de Direito do UNICURITIBA. Curitiba-PR: Unicuritiba. Revista Eletrônica, v. 1, n. 28, p. 77-122, 2012. Disponível em: <http://revista.unicuritiba.edu.br/index.php/RevJur/article/view/412/317>. Acesso em: 08 ago. 2017.

GONÇALVES, Everton das Neves. A tomada de decisão normativo-judicial segundo o Princípio da Eficiência Econômico-Social (PEES). In: POMPEU, Gina Vidal Marcílio; PINTO, Felipe Chiarello de Souza; CLARK, Giovani (Orgs.). Direto e Economia. XXII CONPEDI. São Paulo-SP, p. 319-346.

GONÇALVES, Everton das Neves. O viés econômico do direito justo e eficiente: 0 princípio da eficiência econômico-social. In: OPUSZKA, Paulo Ricardo; SÉLLOS-KNOERR, Viviane Coêlho (Orgs.). Revista Jurídica do Unicuritiba. v. 3, n. 32, p. 128-162. Disponível em: http://revista.unicuritiba.edu.br/index.php/RevJur/article/view/682. Acesso em: 08 ago. 2017.

HOLMES, Stephen. Constituições e constitucionalismo. In: ASENSI, Felipe. PAULA, Daniel Giotti de (orgs.). Tratado de Direito Constitucional. v. 2. Rio de Janeiro: Elsevier, 2014.

HOLMES, Stephen. El Precompromiso y la paradoja de la democracia, in ELSTER, Jon. SLAGSTAD, Rune (orgs). Constitucionalismo y democracia. Fondo de Cultura Economico: México, 1999.

HOLMES, Stephen; SUNSTEIN, Cass R. The cost of rights: why liberty depends on taxes. New York: W. W. Norton \& Company, 1999.

POSNER, Richard A. The Cost of Rights: Implications for Central and Eastern Europe - And for the United States. V. 32. N. 1. Tulsa Law Journal, 1996.

ROCHA, Antônio Sérgio. Genealogia da Constituinte: do autoritarismo à democratização. Lua Nova, v. 88, 2013.

SANTA CATARINA. Comitê Estadual de Monitoramento e Resolução das Demandas de Assistência da Saúde de Santa Catarina - COMESC. Disponível em:

http: / / portalses.saude.sc.gov.br/index.php?option=com_content\&view=article\&id=4949\&ltemid =668. Acesso em: 12 ago. 2017.

SANTA CATARINA. Tribunal de Contas. Parecer prévio sobre as contas prestadas pelo

Governador do Estado de Santa Catarina - exercício 2014. Florianópolis: Tribunal de Contas, 2016.

SANTA CATARINA. Tribunal de Justiça de Santa Catarina. Incidente de Resolução de Demandas Repetitivas n. 0302355-11.2014.8.24.0054/50000. Rio do Sul. Rel.: Des. Ronei Danielli. Julg.: 09 nov. 2016. 
SARLET, Ingo Wolfgang; FIGUEIREDO, Mariana Filchtiner. Reserva do possível, mínimo existencial e direito à saúde: algumas aproximações. In: SARLET, Ingo Wolfgang; TIMM, Luciano Bentti (Org.). Direitos fundamentais: orçamento e "reserva o possível”. 2. ed. rev. e ampl. Porto Alegre: Livraria do Advogado, 2013.

SCHMITT, Carl. Teoria de la Constitución. Madrid: Alianza Editorial [1928], 2006.

SOUZA NETO, Cláudio Pereira de; SARMENTO, Daniel. Controle de constitucionalidade e democracia: algumas teorias e parâmetros de ativismo. In: SARMENTO, Daniel (Coord.). Jurisdição constitucional e política. Rio de Janeiro: Forense, 2015.

WALDRON, Jeremy. Political Political Theory: essays on institutions. Cambridge: Harvard University Press, 2016.

\section{COMO FAZER A REFERÊNCIA DO ARTIGO (ABNT):}

GONÇALVES, Everton das Neves; SILVA, Marco Aurélio Souza da. A judicialização do direito à saúde no constitucionalismo brasileiro: escassez, custos e eficiência econômico-social. Revista Eletrônica do Curso de Direito da UFSM, Santa Maria, RS, v. 13, n. 1, p. 238-264, abr. 2018. ISSN 1981-3694. Disponível em: < https://periodicos.ufsm.br/revistadireito/article/view/29084 >. Acesso em: dia mês. ano. doi: http://dx.doi.org/10.5902/1981369429084 . 